\title{
Surface sealing and water erosion of soils with mulching in the semi-arid region of Brazil
}

\author{
Fábio F. da Silva ${ }^{1}$, Thais E. M. dos S. Souza ${ }^{2}$, Edivan R. de Souza ${ }^{1}$, Marcelo M. Correa $^{1}$ \& Mário M. Rolim ${ }^{1}$ \\ ${ }^{1}$ Universidade Federal Rural de Pernambuco. Recife, PE, Brasil. E-mail: fabioigt.ifce@hotmail.com - ORCID: 0000-0002-3896-6498; edivanrs@hotmail.com \\ (Corresponding author) - ORCID: 0000-0002-2442-7266; marcelometri@yahoo.com - ORCID: 0000-0003-0929-4634; mario.rolim@ufrpe.br - ORCID: \\ 0000-0003-2111-3875 \\ ${ }^{2}$ Universidade Federal de Pernambuco. Recife, PE, Brasil. E-mail: thaisemanuelle@hotmail.com - ORCID: 0000-0003-4768-5839
}

\begin{abstract}
Evaluating soil sealing process of the semi-arid region of Brazil is important to describe this process and mitigate its effects. The objective of this work was to evaluate surface sealing and physical properties of the main soils of the Upper Ipanema watershed, in Pesqueira, Pernambuco state, Brazil, with the use of mulch. The experiment was conducted in a completely randomized design with three replications, using a $3 \times 3 \times 2$ factorial arrangement consisted of three soil classes (abruptic Eutrophic Yellow Argissolo - AEYA, typical Eutrophic Fluvic Neossolo - TEFN, and typical Eutrophic Yellow Argissolo - TEYA), three application times of simulated rainfalls (at 0,24, and $48 \mathrm{~h}$ ), and two mulching conditions (with and without mulch), totaling 54 tests. Soil erosion rates, surface sealing, and resistance to penetration were evaluated. The use of mulch decreased significantly the soil water losses by $71.9 \%$ (AEYA), 62.9\% (TEFN), and 41.1\% (TEYA) after the first rainfall application $(0 \mathrm{~h})$ when compared to treatments without mulch, and promoted a higher water infiltration rate. The lowest soil resistance to penetration were found in soils with mulch. The AEYA and TEFN presented changes in porosity and migration of fine particles in the treatment without mulch. The TENF was the only soil that presented an incipient soil surface sealing layer in the treatment without mulch.
\end{abstract}

Key words: soil micromorphology, simulated rainfall, soil cover

\section{Selamento superficial e erosão hídrica em solos representativos do semiárido brasileiro sob cobertura morta}

RESUMO: A avaliação do processo de selamento superficial em solos da região semiárida Brasileira é de grande relevância para compreensão do processo e tomada de medidas mitigatórias. Objetivou-se avaliar o selamento superficial e características físico-hídricas dos principais solos da Bacia Representativa do Alto Ipanema, Pesqueira-PE, sob influência de cobertura morta. O delineamento experimental foi inteiramente casualizado, em arranjo fatorial 3 × 3 × 2, com três repetições, sendo três solos (Argissolo Amarelo Eutrófico abrúptico, Neossolo Flúvico e Argissolo Amarelo Eutrófico típico), três tempos simulados de aplicação de chuva (0, 24 e $48 \mathrm{~h})$, sem e com cobertura morta, totalizando 54 testes. Avaliaram-se as taxas erosivas, selamento superficial e resistência do solo à penetração. A presença de cobertura morta reduziu significativamente as perdas de água, para o Argissolo Amarelo Eutrófico abrúptico em 71,9\%, para o Neossolo Flúvico em 62,9\% e para o Argissolo Amarelo Eutrófico típico em 41,1\% após a primeira aplicação de chuva ( 0 h), em comparação ao tratamento sem cobertura, proporcionando maior taxa de infiltração. Os menores valores de resistência do solo à penetração foram observados nos solos com cobertura morta. Houve, nos Argissolo abrúptico e Neossolo Flúvico, uma alteração da porosidade das parcelas descobertas e uma migração de material fino. Entre os solos, o Neossolo Flúvico, sem cobertura, foi o único que apresentou uma camada incipiente de selo superficial observada por meio da micromorfologia.

Palavras-chave: micromorfologia do solo, chuva simulada, cobertura do solo 


\section{INTRODUCTION}

Inadequate soil management practices favor the formation of surface crusts, which reduce water infiltration and favor surface runoff, making it difficult for seedlings to emerge and growth of root systems (Lima et al., 2015).

Soil water erosion caused by surface runoff is more intense in areas without vegetation because the energy of the impact of raindrops disaggregates and carries soil particles more easily in these areas (Silva et al., 2010). The direct action of rainfall on the soil surface and the carrying of particles due to soil disaggregation modify the soil surface structure, leading to the development of surface sealing (Sandin et al., 2018).

The formation process of soil surface sealing occurs in the first few centimeters of the soil and affects several processes related to soil structuring; this process can be observed directly due to changes in the soil morphology, or indirectly due to the decreased water infiltration capacity and increased soil surface resistance to penetration (Rosa et al., 2013). Soil micromorphological analyses can be used to assess changes in soil structure and porous spaces in areas under degradation process (Lima et al., 2005). Moreover, these analyses can show micromorphological changes in the soil surface structure and their effects on hydraulic conductivity and on water infiltration, which are important for regions that present water shortages (Castro et al., 2006).

Thus, the objective of this work was to evaluate the surface sealing and physical properties of the main soils of the Upper Ipanema watershed, in Pesqueira, Pernambuco state, Brazil, with the use of mulch.

\section{Material AND Methods}

The three soils sampled for this study were from the Upper Ipanema watershed, in Pesqueira, state of Pernambuco, Brazil ( $8^{\circ} 21^{\prime} 28^{\prime \prime} \mathrm{S}, 36^{\circ} 41^{\prime} 45^{\prime \prime} \mathrm{W}$, and $654 \mathrm{~m}$ of altitude). The region has average annual temperature of $23{ }^{\circ} \mathrm{C}$, average annual evapotranspiration potential of $2000 \mathrm{~mm}$, and average annual precipitation of $607 \mathrm{~mm}$.

The soils evaluated were classified by the EMBRAPA (2013) as abruptic Eutrophic Yellow Argissolo (AEYA), typical Eutrophic Fluvic Neossolo (TEFN), and typical Eutrophic Yellow Argissolo (TEYA). The chemical and physical properties of these soils are shown in Table 1.
Soil samples from the $0-0.20 \mathrm{~m}$ layer were collected in January 2015 in three different areas. These samples were air dried, disaggregated, and sieved in a $4 \mathrm{~mm}$ mesh sieve to preserve soil microaggregates. Then, the samples were distributed into experimental plots according to the soil density measured in the field. The experiment was conducted at the Federal Rural University of Pernambuco, Recife, Pernambuco state, Brazil.

The experiment was conducted in a completely randomized design with three replications, using a $3 \times 3 \times 2$ factorial arrangement consisted of three soils, three application times of simulated rainfalls (at 0,24 , and $48 \mathrm{~h}$ ), and two mulching conditions (with and without mulch), totaling 54 tests.

Air-dried Brachiaria decumbens grass at density of $3 \mathrm{Mg} \mathrm{ha}^{-1}$ was used as mulch to evaluated the effects of erosive factors on the soil. The rainfall simulator used was equipped with a Veejet 80-100 spray nozzle in the center of the bar, at $3 \mathrm{~m}$ above the ground, and a manometer (Santos et al., 2009). The simulated rainfall depths used were based on a 29-year historical data series of the Upper Ipanema watershed (Santos \& Montenegro, 2012). The simulated rainfalls had duration of $30 \mathrm{~min}$ and intensity of $96.6 \mathrm{~mm} \mathrm{~h}^{-1}$, representing a return period of 2 years, with probability of occurrence of $75 \%$, and erosivity index $\left(\mathrm{EI}_{30}\right)$ of $2,415.33 \mathrm{MJ} \mathrm{mm} \mathrm{ha}{ }^{-1} \mathrm{~h}^{-1}$.

The plots were $1.00 \mathrm{~m}$ long, $0.50 \mathrm{~m}$ wide, $0.20 \mathrm{~m}$ deep, with a slope of $0.09 \mathrm{~m} \mathrm{~m}^{-1}$. Three drain holes spaced $0.17 \mathrm{~m}$ apart at the bottom of the plots conducted the water through a single collecting drain to a flume that allowed the collection of the surface runoff using test tubes; the samples were collected for ten-seconds with five-minute intervals. Three successive rainfalls were simulated with 24 hours intervals $(0,24$, and $48 \mathrm{~h}$ ) to evaluate the effects of surface sealing on soil erosive rates.

The water loss was determined by the ratio between the surface runoff depth and the total rainfall depth. Water infiltration rate was determined by the difference between the total rainfall depth and the surface runoff.

The material used to determine soil loss rates, and sediment concentration was collected for 10 seconds in $1 \mathrm{~L}$ plastic pots with five-minute intervals, weighed and left to rest for $24 \mathrm{~h}$; the supernatant was then pipetted, separating it from the solid material at the bottom of the containers. The pots were dried in an oven at $65^{\circ} \mathrm{C}$ for $72 \mathrm{~h}$ to obtain the soil dry weight, according to the procedure described by Cogo (1978).

The soil disaggregation rates (SDR) $\left(\mathrm{kg} \mathrm{m}^{-2} \mathrm{~s}^{-1}\right)$ were determined according to Eq. 1:

Table 1. Physical and chemical properties of the 0-0.20 m soil layer of the abruptic Eutrophic Yellow Argissolo (AEYA), typical Eutrophic Fluvic Neossolo (TEFN), and typical Eutrophic Yellow Argissolo (TEYA) used in the experiment

\begin{tabular}{|c|c|c|c|c|c|c|c|c|c|c|c|c|}
\hline \multirow[t]{2}{*}{ Soil } & $\begin{array}{l}\text { Total } \\
\text { sand }\end{array}$ & $\begin{array}{c}\text { Coarse } \\
\text { sand }\end{array}$ & $\begin{array}{l}\text { Fine } \\
\text { sand }\end{array}$ & Clay & Silt & CDW & DF & TP & SD & PD & \multirow{2}{*}{$\begin{array}{c}\mathrm{K}_{0} \\
\left(\mathbf{c m ~ h} \mathbf{h}^{-1}\right)\end{array}$} & \multirow[t]{2}{*}{ Textural class } \\
\hline & \multicolumn{5}{|c|}{$\left(\mathrm{g} \mathrm{kg}^{-1}\right)$} & \multicolumn{3}{|c|}{$(\%)$} & \multicolumn{2}{|c|}{$\left(\mathrm{g} \mathrm{cm}^{-3}\right)$} & & \\
\hline AEYA & 722 & 533 & 189 & 167 & 111 & 6.8 & 79.92 & 52 & 1.45 & 2.76 & 30.7 & Sandy loam \\
\hline TEFN & 613 & 409 & 204 & 207 & 180 & 7.6 & 79.5 & 51 & 1.43 & 2.76 & 17.8 & Sandy clay loam \\
\hline TEYA & 679 & 405 & 274 & 170 & 151 & 7.2 & 76.72 & 57 & 1.45 & 2.52 & 22.6 & Sandy loam \\
\hline \multirow{2}{*}{ Soil } & \multirow{2}{*}{$\begin{array}{c}\mathrm{pH} \\
\mathrm{H}_{2} \mathrm{O}\end{array}$} & \multirow{2}{*}{$\begin{array}{c}\text { EC } \\
\left(\mathrm{dS} \mathrm{m}^{-1}\right)\end{array}$} & $\mathrm{Ca}$ & $\mathrm{Mg}$ & & & $\mathrm{Na}$ & $\overline{\mathrm{AI}}$ & $\mathrm{H}+\mathrm{Al}$ & & OM & OC \\
\hline & & & \multicolumn{7}{|c|}{$\left(\mathrm{cmol}_{\mathrm{c}} \mathrm{dm}^{-3}\right)$} & \multicolumn{3}{|c|}{$\left(g^{k g-1}\right)$} \\
\hline AEYA & 6.05 & 0.15 & 1.55 & 2.5 & & & .043 & 0.11 & 2.72 & & 24.02 & 13.96 \\
\hline TEFN & 5.80 & 0.17 & 3.45 & 3.7 & & & .087 & 0.09 & 2.72 & & 25.15 & 14.62 \\
\hline TEYA & 6.00 & 0.13 & 1.75 & 1.8 & & & .065 & 0.12 & 2.64 & & 18.74 & 10.9 \\
\hline
\end{tabular}

CDW - Clay dispersed in water; DF - Degree of flocculation; TP - Total porosity; SD - Soil density; PD - Particle density; $\mathrm{K}_{0}$ - Hydraulic conductivity; EC - Electrical conductivity; OM - Organic matter; OC - Organic carbon 


$$
\mathrm{SDR}=\frac{\mathrm{DSDW}}{\mathrm{PASS}}
$$

where:

DSDW - disaggregated soil dry weight $(\mathrm{kg})$;

PA - plot area $\left(\mathrm{m}^{2}\right)$; and,

SS - sampling span (s).

The soil loss (SL) rate $\left(\mathrm{kg} \mathrm{m}^{-2}\right)$ was determined according to Eq. 2:

$$
\mathrm{SL}=\frac{\sum(\mathrm{Q} \mathrm{SC} T \mathrm{~S})}{\mathrm{PA}}
$$

where:

$\mathrm{Q}$ - flow rate $\left(\mathrm{L} \mathrm{s}^{-1}\right)$;

SC - sediment concentration $\left(\mathrm{kg} \mathrm{L}^{-1}\right)$;

TS - time interval between samplings (s); and,

PA - plot area $\left(\mathrm{m}^{2}\right)$.

The water loss (WL; \%), considering the surface runoff volume, was determined according to Eq. 3:

$$
\mathrm{WL}=\left(\frac{\mathrm{SR}}{\mathrm{TRD}}\right) 100
$$

where:

SR - surface runoff ( $\mathrm{mm})$; and,

TRD - total rainfall depth ( $\mathrm{mm})$.

Three undisturbed samples were collected from each soil using rings ( $5 \mathrm{~cm}$ diameter and $5 \mathrm{~cm}$ height) at $24 \mathrm{~h}$ after each simulated rainfall to evaluate soil resistance to penetration. These samples were placed in a Richard's pressure chamber $(10 \mathrm{kPa})$ until the samples were stable; then, they were weighed to determine their moisture. Soil resistance to penetration was determined using a bench penetrometer with nominal load capacity of $20 \mathrm{~kg}$, operating at a speed of $1 \mathrm{~cm} \mathrm{~min}^{-1}$, with a base cone thickness of $4 \mathrm{~mm}$. The data were provided by a computer connected to the equipment, with readings performed to the depth of $0.02 \mathrm{~m}$ to evaluate soil resistance to penetration.

Surface sealing was assessed through morphological description of polished soil blocks. PVC-tube slices $(15 \mathrm{~cm}$ diameter and $15 \mathrm{~cm}$ height) were used for micromorphological analysis. Two undisturbed soil samples were collected in each of the three plots with mulch and the three plots without mulch, at $24 \mathrm{~h}$ after the first and the last simulated rainfall, totaling 24 samples. The collected materials were air dried for seven days to uniformize the amount of water. The impregnation was carried out according to the method proposed by Murphy et al. (1977) with adaptations (Murphy, 1986; Castro et al., 2003; Rosa et al., 2013).

After the blocks were completely impregnated and hardened, slices with thickness of approximately $0.5 \mathrm{~cm}$ were cut and used to prepare 12 slides $(2.6 \times 7.6 \mathrm{~cm})$ for analyses in light microscopy. This procedure was performed in the Department of Geology of the Federal University of Pernambuco. Each slice was placed onto a glass slide $(2.6 \times 7.6 \mathrm{~cm})$ and the block was polished using a mechanical sander. Subsequently, a manual polishing with a 6 to $12 \mu \mathrm{m}$ paste was carried out until the slices reached the desired thickness $(30 \mu \mathrm{m})$. The thickness was uniform in all slides; it was controlled using a microscope by means of undulatory extinction in quartz.

The micromorphological description of the samples was performed to present the features and general characterization of slides for the different soils and simulated rainfalls. The microscopic micromorphological description was then performed, following the criteria proposed by Bullock et al. (1985) and Rosa et al. (2013), considering the dynamics of the surface sealing process in the three soils (with and without mulch) after the simulated rainfalls ( 0 and $48 \mathrm{~h}$ ).

The runoff hydraulic characteristics, soil water losses, aggregate stability, and soil resistance to penetration were evaluated through analysis of variance (ANOVA) and Tukey's test at 0.05 significance level.

\section{Results AND Discussion}

The use of mulch to cover the soils reduced soil loss, disaggregation rate, and water loss compared to the soils without mulch. The soil classes and times of simulated rainfalls $(0,24$, and $48 \mathrm{~h})$ had no significant interaction with the soil cover (Table 2).

The use of mulch reduced soil loss by controlling water erosion. It minimized the kinetic energy of the raindrops on the

\begin{tabular}{|c|c|c|c|c|c|c|}
\hline \multirow{2}{*}{$\begin{array}{l}\text { Time of simulated } \\
\text { rainfalls (hours) }\end{array}$} & \multicolumn{2}{|c|}{ Soil loss $\left(\mathrm{kg} \mathrm{m}^{-2}\right)$} & \multicolumn{2}{|c|}{ Soil disaggregation rate $\left(\mathrm{kg} \mathrm{m}^{-2} \mathrm{~s}^{-1}\right)$} & \multicolumn{2}{|c|}{ Water loss (\%) } \\
\hline & $\mathrm{NM}$ & WM & NM & WM & $\overline{\mathrm{NM}}$ & $\overline{\text { WM }}$ \\
\hline & \multicolumn{6}{|c|}{ abruptic Eutrophic Yellow Argissolo - AEYA } \\
\hline 0 & $0.0375 \mathrm{aA}$ & $0.0239 \mathrm{aB}$ & $4.44 \times 10^{-6} \mathrm{aA}$ & $2.41 \times 10^{-6} \mathrm{aB}$ & $77.6 \mathrm{aA}$ & $71.9 \mathrm{bB}$ \\
\hline 24 & $0.0389 \mathrm{aA}$ & $0.0247 \mathrm{aB}$ & $4.55 \times 10^{-6} \mathrm{aA}$ & $2.55 \times 10^{-6} \mathrm{aB}$ & $83.0 \mathrm{aA}$ & $74.0 \mathrm{abB}$ \\
\hline 48 & $0.0497 \mathrm{aA}$ & $0.0252 \mathrm{aB}$ & $5.0 \times 10^{-6} \mathrm{aA}$ & $2.59 \times 10^{-6} \mathrm{aB}$ & $84.0 \mathrm{aA}$ & $75.0 \mathrm{aB}$ \\
\hline \multicolumn{7}{|c|}{ typical Eutrophic Fluvic Neossolo - TEFN } \\
\hline 0 & $0.0379 \mathrm{aA}$ & $0.0275 \mathrm{aB}$ & $3.70 \times 10^{-6} \mathrm{aA}$ & $2.66 \times 10^{-6} \mathrm{aB}$ & $76.8 \mathrm{aA}$ & $62.9 \mathrm{bB}$ \\
\hline 24 & $0.0441 \mathrm{aA}$ & $0.0287 \mathrm{aB}$ & $4.07 \times 10^{-6} \mathrm{aA}$ & $2.67 \times 10^{-6} \mathrm{aB}$ & $78.2 \mathrm{aA}$ & $69.1 \mathrm{aB}$ \\
\hline 48 & $0.0455 \mathrm{aA}$ & $0.0296 \mathrm{aB}$ & $4.26 \times 10^{-6} \mathrm{aA}$ & $2.92 \times 10^{-6} \mathrm{aB}$ & $79.9 \mathrm{aA}$ & $69.4 \mathrm{aB}$ \\
\hline \multicolumn{7}{|c|}{ typical Eutrophic Yellow Argissolo - TEYA } \\
\hline 0 & $0.0545 \mathrm{aA}$ & $0.0098 \mathrm{aB}$ & $4.57 \times 10^{-6} \mathrm{aA}$ & $2.70 \times 10^{-6} \mathrm{aB}$ & $79.7 \mathrm{aA}$ & $41.1 \mathrm{bB}$ \\
\hline 24 & $0.0568 \mathrm{aA}$ & $0.0291 \mathrm{aB}$ & $4.81 \times 10^{-6} \mathrm{aA}$ & $2.78 \times 10^{-6} \mathrm{aB}$ & $81.4 \mathrm{aA}$ & $75.1 \mathrm{aB}$ \\
\hline 48 & $0.0577 \mathrm{aA}$ & $0.0340 \mathrm{aB}$ & $5.04 \times 10^{-6} \mathrm{aA}$ & $3.33 \times 10^{-6} \mathrm{aB}$ & $86.0 \mathrm{aA}$ & $77.9 \mathrm{aB}$ \\
\hline
\end{tabular}
soil surface by reducing the exposure of the soil, thus avoiding

Table 2. Soil loss, disaggregation rate, and water loss of different soils in treatments with (WM) and without mulch (NM)

Means followed by same lowercase letters in the columns and uppercase letters in rows do not differ by the Tukey's test at 0.05 probability 
the detachment of soil particles. Lima et al. (2015) evaluated agricultural practices in cassava crops and their relationship with soil losses and found that the use of plant residues on the soil surface reduced soil disaggregation and assisted in dissipate the kinetic energy of raindrops, decreasing soil loss.

The treatments without mulching presented water losses of $77.6 \%$ (AEYA), 76.8\% (TEFN), and 79.7\% (TEYA), after the first simulated rainfall. The use of mulch reduced water loss, with the lowest water losses found for TEYA and TEFN after the first simulated rainfall $(0 \mathrm{~h})$ (Table 2). Santos et al. (2009), Silva et al. (2011) and Albuquerque et al. (2002) found similar results.

Regarding the soil disaggregation rate (Table 2), it was observed that there was no statistical difference between the times of simulated rainfalls. The difference occurred only between the soil cover, since the presence of the mulch presents a barrier preventing soil disaggregation.

The use of mulch decreased surface runoff, denoting the importance of soil cover to the reduction of water losses. Soils of treatments without mulch presented less water infiltration and, thus, greater surface runoff and less time to start the runoff (Table 3).

The use of mulch increased water infiltration rate in the three evaluated soil classes. Santos et al. (2009) and Lima et al. (2015) also concluded that water loss due to surface runoff decreases with increasing runoff starting time and unprotected soils have low water infiltration.

Significant differences were found for soil resistance to penetration between treatments with, and without mulch (Table 4).

In the plots without mulch, the highest soil resistance to penetration were found after the simulated rainfall at $48 \mathrm{~h}$, denoting a soil densification due to the successive high-intensity simulated rainfalls. Soil resistance to penetration has been an important parameter to evaluate soil physical quality (BlancoCanqui \& Ruis, 2018).

In the plots with mulch, no significant statistical differences between treatments were found, denoting the efficiency of the mulch in reducing soil surface layer compaction, even under high-intensity rainfall conditions.

According to Hamza \& Anderson (2005), soil resistances to penetration between 2 and $3 \mathrm{MPa}$ limit root development of several crop species. The soil resistances to penetration found in the present work were below this limit, probably because
Table 4. Resistance to penetration, and percentage of moisture in the 0-0.02 m layer of different soils in treatments with (WM) and without mulch (NM) after simulated rainfalls with 24hour intervals

\begin{tabular}{|c|c|c|c|c|}
\hline \multirow{2}{*}{$\begin{array}{l}\text { Time of simulated } \\
\text { rainfalls (hours) }\end{array}$} & \multicolumn{2}{|c|}{$\begin{array}{c}\text { Soil resistance } \\
\text { to penetration (MPa) }\end{array}$} & \multicolumn{2}{|c|}{$\begin{array}{c}\text { Percentage } \\
\text { of moisture (\%) }\end{array}$} \\
\hline & NM & WM & NM & WM \\
\hline & \multicolumn{4}{|c|}{ abruptic Eutrophic Yellow Argissolo - AEYA } \\
\hline 0 & $0.045 \mathrm{bA}$ & $0.015 \mathrm{aB}$ & $17.3 \mathrm{aB}$ & $20.1 \mathrm{aA}$ \\
\hline 24 & $0.093 \mathrm{bA}$ & $0.027 \mathrm{aB}$ & $15.1 \mathrm{abB}$ & $18.0 \mathrm{aA}$ \\
\hline \multirow[t]{2}{*}{48} & $0.150 \mathrm{aA}$ & $0.055 \mathrm{aB}$ & $14.2 \mathrm{bB}$ & $17.9 \mathrm{aA}$ \\
\hline & \multicolumn{4}{|c|}{ typical Eutrophic Fluvic Neossolo - TEFN } \\
\hline 0 & $0.052 \mathrm{bA}$ & $0.025 \mathrm{aB}$ & $19.6 \mathrm{aB}$ & $20.6 \mathrm{aA}$ \\
\hline 24 & $0.064 \mathrm{bA}$ & $0.027 \mathrm{aB}$ & $17.8 \mathrm{bB}$ & $19.4 \mathrm{aA}$ \\
\hline \multirow[t]{2}{*}{48} & $0.148 \mathrm{aA}$ & $0.042 \mathrm{aB}$ & $15.1 \mathrm{cB}$ & $18.5 \mathrm{aA}$ \\
\hline & \multicolumn{4}{|c|}{ typical Eutrophic Yellow Argissolo - TEYA } \\
\hline 0 & $0.040 \mathrm{bA}$ & $0.016 \mathrm{aB}$ & $18.7 \mathrm{aB}$ & $19.8 \mathrm{aA}$ \\
\hline 24 & $0.052 \mathrm{bA}$ & $0.042 \mathrm{aB}$ & $17.1 \mathrm{abB}$ & $18.9 \mathrm{aA}$ \\
\hline 48 & $0.098 \mathrm{aA}$ & $0.064 \mathrm{aB}$ & $15.5 \mathrm{bB}$ & $18.0 \mathrm{aA}$ \\
\hline
\end{tabular}

Means followed by lowercase letters in the columns and uppercase letters in the rows do not differ by the Tukey's test at 0.05 probability

measurements were made with tensions similar to the moisture at field capacity $(10 \mathrm{kPa})$.

The presence of surface cover was efficient to maintain the percentage of moisture in the $0.02 \mathrm{~m}$ layer, differing significantly from the uncovered treatment (no mulch). For the treatment with cover (with mulch), no difference was observed in this variable between the time of simulated rainfalls, unlike the uncovered soil condition, that the highest percentage of moisture was observed after the first application of the time of simulated rainfall, so that with the application of rainfall after $48 \mathrm{~h}$, soil moisture was already significantly lower than the first condition, evidencing that without the presence of cover, the water content in the soil is not maintained.

According to the morphological description of the micrographs of the three soils without mulch, the distribution was, in general, heterogeneous to the AEYA and TEFN ( 0 and $48 \mathrm{~h})$ with materials in four zones $\mathrm{A}, \mathrm{B}, \mathrm{C}$ and $\mathrm{D}$ and homogeneous for the TEYA ( 0 and $48 \mathrm{~h}$ ), in the zones of $\mathrm{E}$ and $\mathrm{F}$ (Figure 1 ).

These soils are composed predominantly of quartz, followed by feldspars, fragments of rock, and micas (muscovite). Little fragments of well-preserved roots were found. The soil mineral coarse fraction had varied sizes and well-preserved edges (subangular to subrounded), indicating low contribution of the sedimentary material to the soil formation.

Table 3. Surface runoff, water infiltration and runoff starting time for the different soils with (WM) and without mulch (NM)

\begin{tabular}{|c|c|c|c|c|c|c|}
\hline \multirow{2}{*}{$\begin{array}{l}\text { Time of simulated } \\
\text { rainfalls (hours) }\end{array}$} & \multicolumn{2}{|c|}{ Surface runoff $\left(\mathrm{mm} \mathrm{h}^{-1}\right)$} & \multicolumn{2}{|c|}{ Water infiltration rate $\left(\mathrm{mm} \mathrm{h}^{-1}\right)$} & \multicolumn{2}{|c|}{ Runoff starting time (min) } \\
\hline & NM & WM & NM & WM & NM & WM \\
\hline & \multicolumn{6}{|c|}{ abruptic Eutrophic Yellow Argissolo - AEYA } \\
\hline 0 & $76.8 \mathrm{aA}$ & $75.6 \mathrm{aB}$ & $19.7 \mathrm{aB}$ & $21.0 \mathrm{aA}$ & $5.0 \mathrm{aB}$ & $6.6 \mathrm{aA}$ \\
\hline 24 & $75.0 \mathrm{aA}$ & $69.2 \mathrm{aB}$ & $21.8 \mathrm{aB}$ & $27.6 \mathrm{aA}$ & $4.0 \mathrm{aB}$ & $4.7 \mathrm{aA}$ \\
\hline \multirow[t]{2}{*}{48} & $81.2 \mathrm{aA}$ & $80.0 \mathrm{aB}$ & $15.5 \mathrm{aB}$ & $16.7 \mathrm{aA}$ & $4.0 \mathrm{aB}$ & $4.7 \mathrm{aA}$ \\
\hline & \multicolumn{6}{|c|}{ typical Eutrophic Fluvic Neossolo - TEFN } \\
\hline 0 & $73.6 \mathrm{aA}$ & $63.2 \mathrm{aB}$ & $23.1 \mathrm{aB}$ & $33.5 \mathrm{aA}$ & $5.3 \mathrm{aB}$ & $11.0 \mathrm{aA}$ \\
\hline 24 & $74.5 \mathrm{aA}$ & $68.3 \mathrm{aB}$ & $22.1 \mathrm{aB}$ & $28.4 \mathrm{bA}$ & $4.3 \mathrm{aB}$ & $11.0 \mathrm{aA}$ \\
\hline \multirow[t]{2}{*}{48} & $74.6 \mathrm{aA}$ & $68.3 \mathrm{aB}$ & $22.2 \mathrm{aB}$ & $28.4 \mathrm{bA}$ & $3.6 \mathrm{aB}$ & $9.0 \mathrm{aA}$ \\
\hline & \multicolumn{6}{|c|}{ typical Eutrophic Yellow Argissolo - TEYA } \\
\hline 0 & $82.4 \mathrm{aA}$ & $41.8 \mathrm{bB}$ & $14.3 \mathrm{aB}$ & $54.9 \mathrm{aA}$ & $9.0 \mathrm{aB}$ & $21.0 \mathrm{aA}$ \\
\hline 24 & $77.3 \mathrm{aA}$ & $72.6 \mathrm{aB}$ & $19.4 \mathrm{aB}$ & $24.1 \mathrm{bA}$ & $4.3 \mathrm{aB}$ & $6.33 \mathrm{bA}$ \\
\hline 48 & $85.5 \mathrm{aA}$ & $76.8 \mathrm{aB}$ & $10.5 \mathrm{aB}$ & $19.7 \mathrm{bA}$ & $3.6 \mathrm{aB}$ & $5.67 \mathrm{bA}$ \\
\hline
\end{tabular}

Means followed by same lowercase letters in the columns, and uppercase letters in the rows do not differ by the Tukey's test at 0.05 probability 
A.

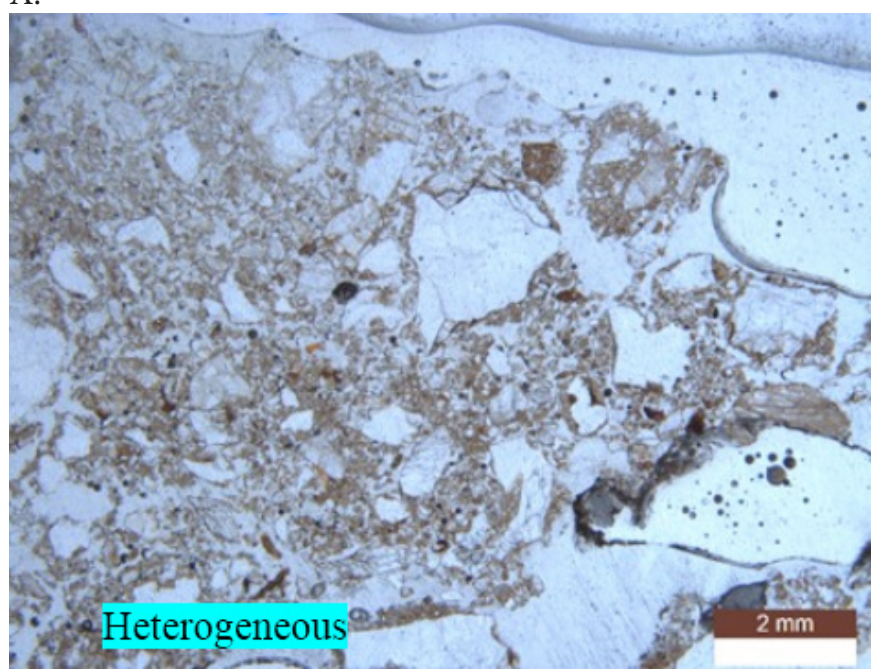

C.

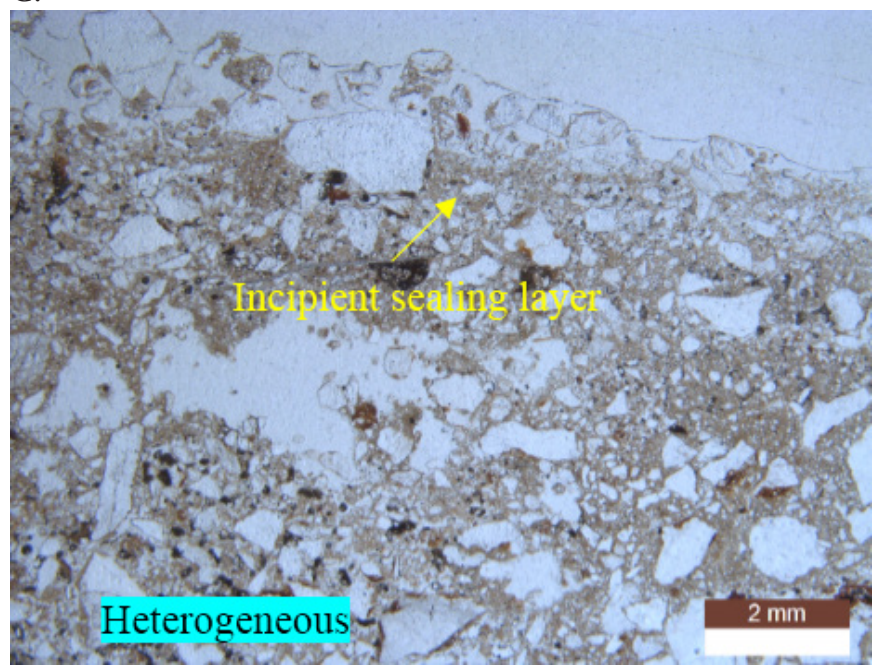

E.

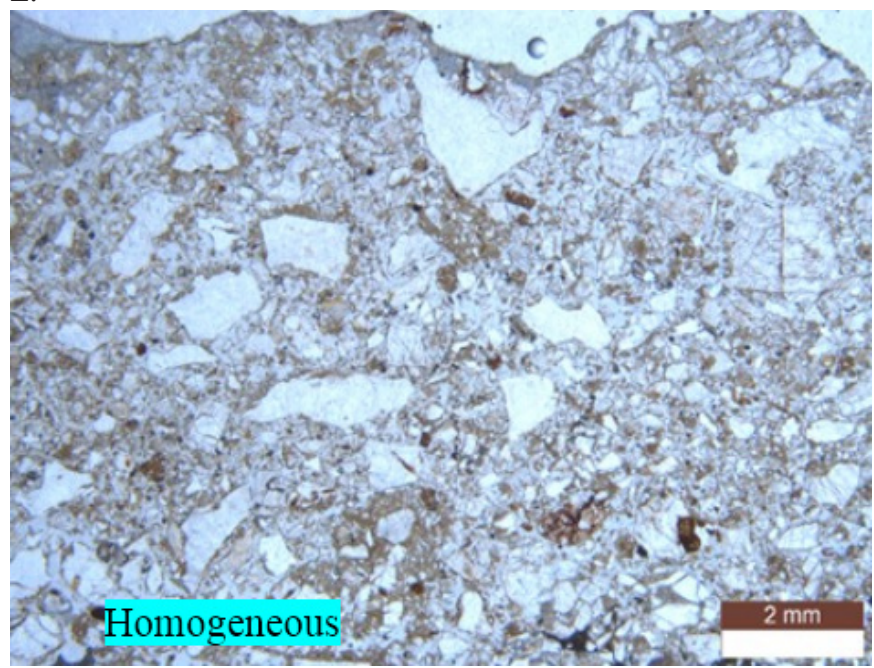

B.

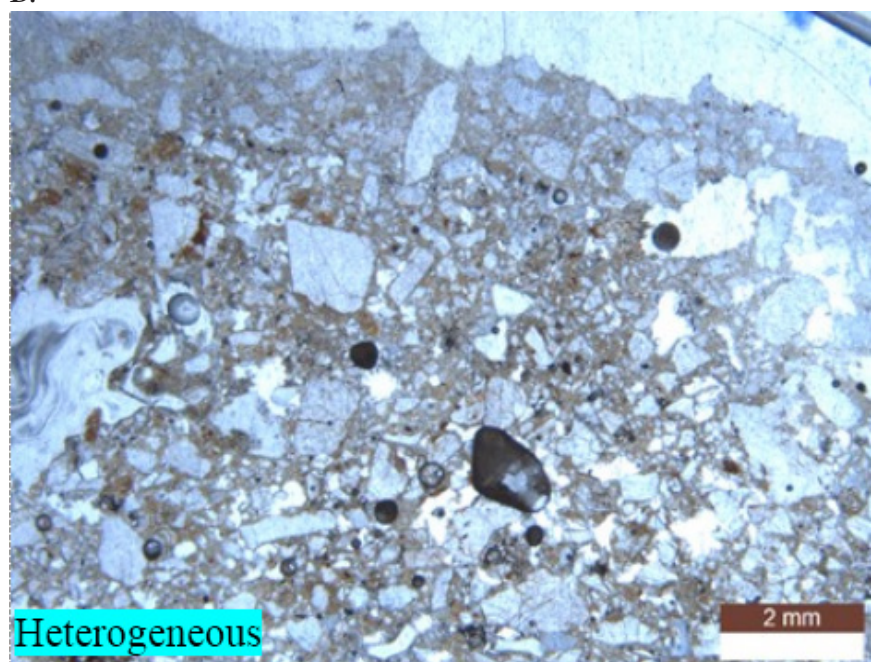

D.

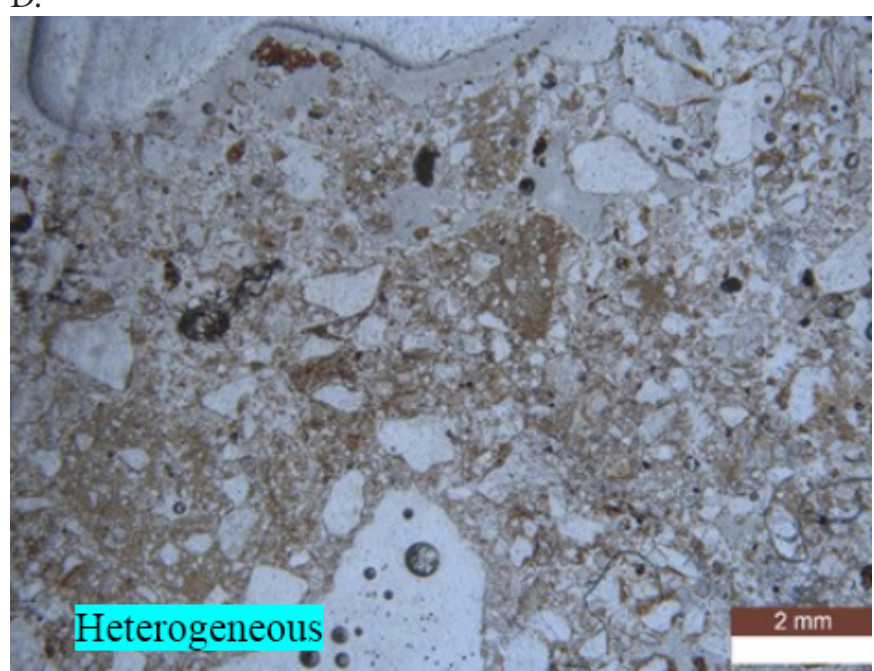

F.

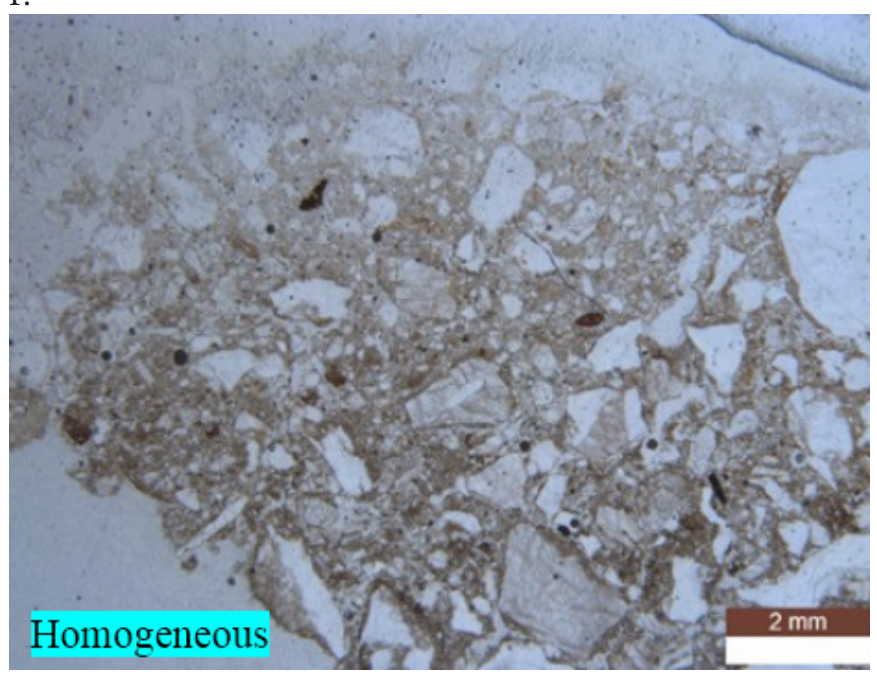

Figure 1. Micrograph of the soil surface layer as a function of two simulated rainfall applied at $0 \mathrm{~h}(\mathrm{~A})$ and $48 \mathrm{~h}(\mathrm{~B})$ on an abruptic Eutrophic Yellow Argissolo (AEYA), at $0 \mathrm{~h}$ (C) and $48 \mathrm{~h}$ (D) on a typical Eutrophic Fluvic Neossolo (TEFN), and at 0 h (E) and $48 \mathrm{~h}$ (F) on a typical Eutrophic Yellow Argissolo (TEYA), without mulch

The fine material presented predominance of kaolinite, as shown by its high optical isotropy. The analysis showed small anisotropic zones, in scattered grainy b-fabric form, dispersed in the fine soil matrix. Its color varied little among soils, always in yellowish shades (pale to dark yellow).

According to the relative distribution of the samples, the AEYA and TEYA soils without mulching showed porphyric distribution at $48 \mathrm{~h}$; and the TEFN showed porphyric distribution after the first simulated rainfall $(0 \mathrm{~h})$. An incipient layer of surface seal at the top of zone A was found for the TEFN at $0 \mathrm{~h}$, with diverse quartz particles on the sample surface and on a small area below, which apparently was better settled, followed by large cavities, aligned and parallel to the surface of the slide (Figure 1). 
The micromorphological characteristics of classification, packing, and disposition of the soil coarse and fine particles are dependent on the hydrodynamic sedimentation conditions of the particles (Valentin \& Bresson, 1992; Rosa et al., 2013).

The samples of the TEFN and TEYA with mulch $(0$ and $48 \mathrm{~h}$ ) presented, in general, homogeneous distribution, and

A.

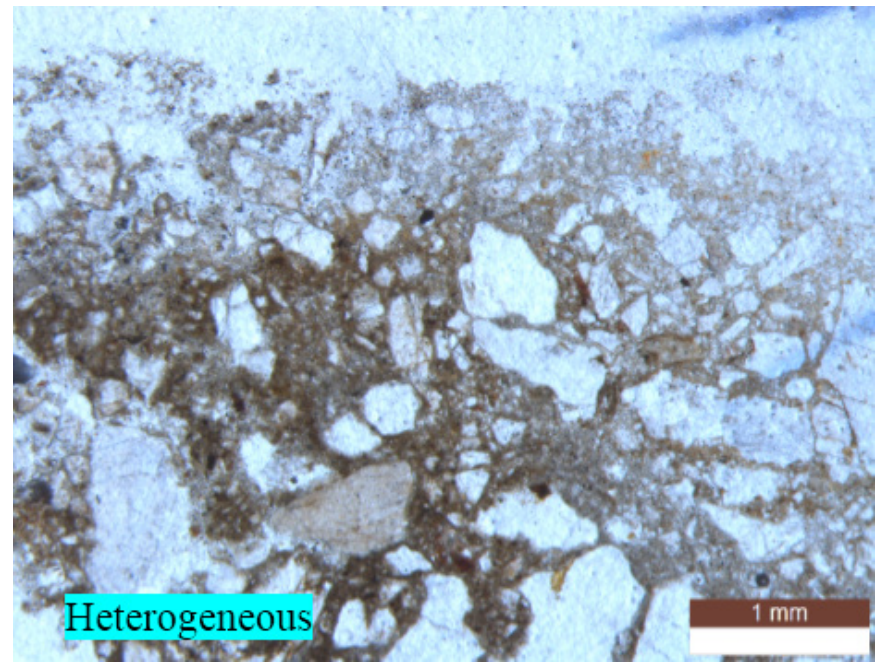

C.

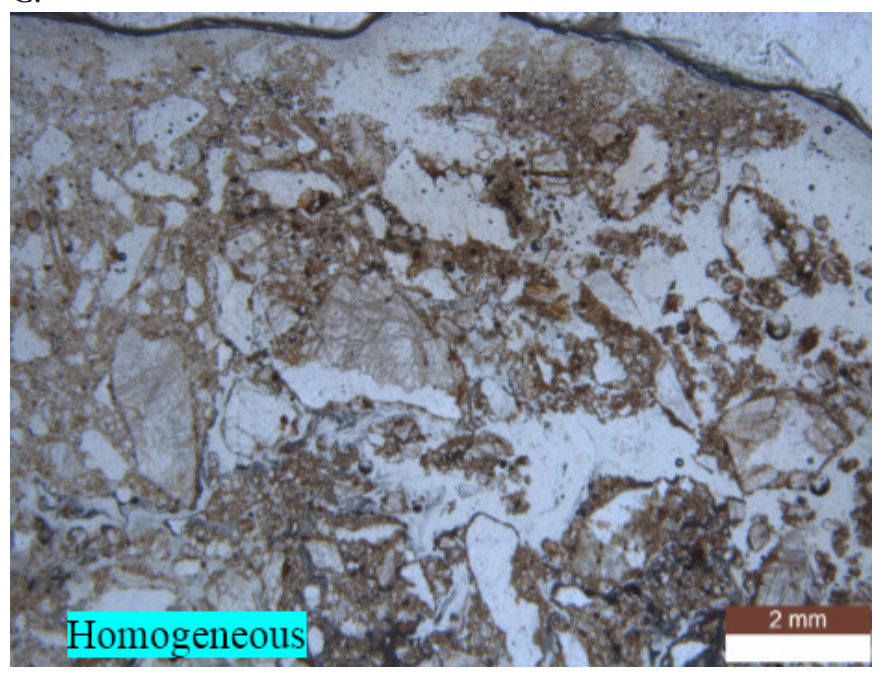

E.

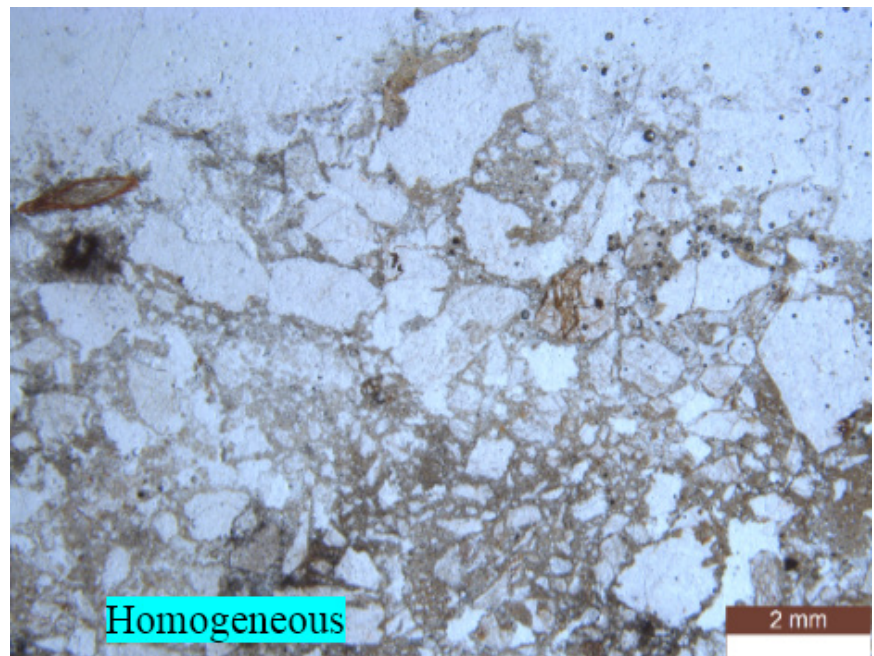

smaller porosities were found in slides of samples collected after the simulated rainfall at $48 \mathrm{~h}$ (Figures 2C, D, E and F). Contrastingly, after this simulated rainfall, the AEYA showed a heterogeneous distribution, with little coarse particles $(\mathrm{D}=$ $0.6 \mathrm{~mm}$ ), and at the top of this zone a very thin layer of sand and silt was found on the surface of the soil (Figures $2 \mathrm{~A}$ and $\mathrm{B}$ ).

B.

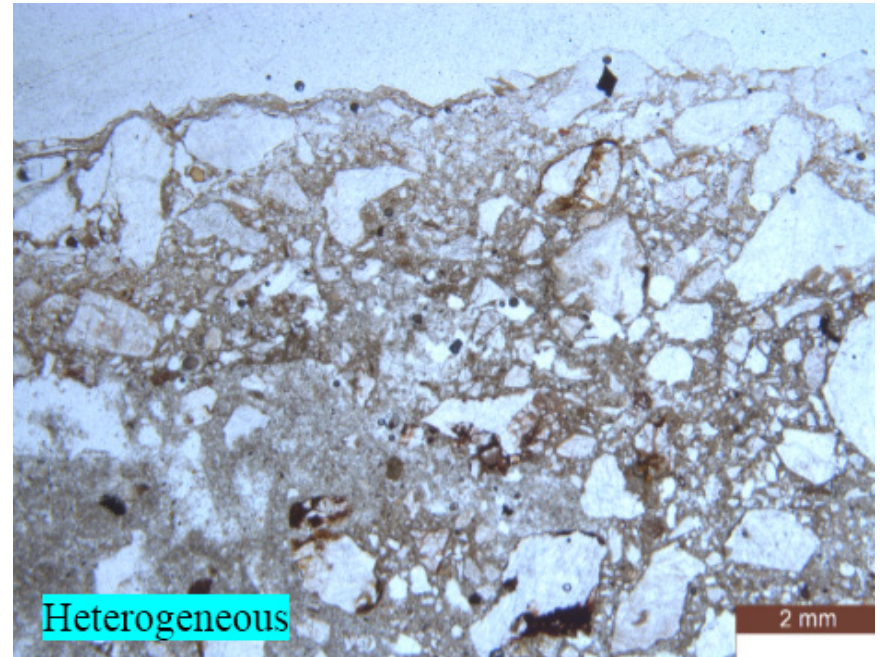

D.

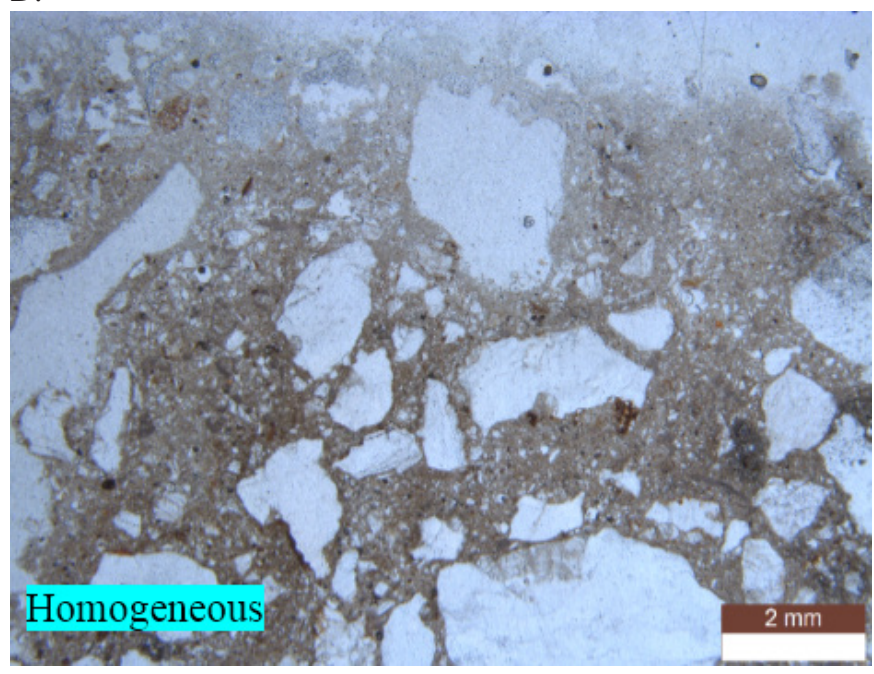

F.

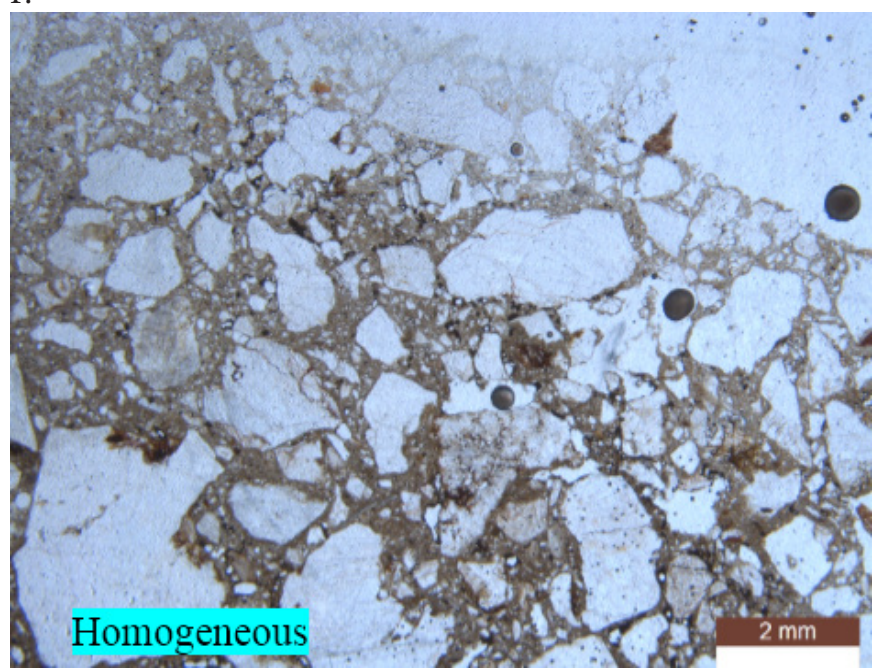

Figure 2. Micrograph of the soil surface layer as a function of two simulated rainfall applied at $0 \mathrm{~h}(\mathrm{~A})$ and $48 \mathrm{~h}$ (B) on an abruptic Eutrophic Yellow Argissolo (AEYA), at $0 \mathrm{~h}$ (C) and $48 \mathrm{~h}$ (D) on a typical Eutrophic Fluvic Neossolo (TEFN), and at 0 $\mathrm{h}(\mathrm{E})$ and $48 \mathrm{~h}(\mathrm{~F})$ on a typical Eutrophic Yellow Argissolo (TEYA), with mulch 
According to Fox et al. (2004), changes in soil surface conditions depend on soil texture, mineralogy, organic matter, initial moisture, distribution, and size and stability of soil aggregates. The surface of soils with mulch had little changes, presenting massive formation, aggregate fragments, and low frequency of cavity porosity (Figure 2).

Castro et al. (2003) reported that cavities are large pores that have spherical to elongate, and sometimes irregular shapes.

In general, soil surface sealing was not found in the soil samples evaluated, regardless of the use of mulching, even after the successive simulated rainfall. This was probably due to the lack of aggregation in these soils, which did not allow the visualization of microstructural contrast between the soil surface sealing and subsurface; and the insufficient wetting and drying cycles for the fine material reorganization. These criteria seem to be essential for the surface sealing of the studied soils.

According to Castro et al. (2003), changes in particle organization on the soil surface caused by the impact of raindrops are important for the soil surface sealing. Thus, this process occurs through wetting and drying cycles, which promote selective fragmentation of aggregates. Constant wetting and drying cycles and large temperature fluctuations can hinder soil water use and increase surface runoff, resulting in soil surface sealing (Borges et al., 2014). Fox et al. (2004) reported that wetting and drying processes cause hardening of soil surface layers, compromising water infiltration and increasing soil physical resistance along several rainfall events with drought periods between them.

\section{Conclusions}

1. The use of mulch for soil management decreases significantly soil erosion, surface runoff, and soil resistance to penetration, and increases water infiltration.

2. The timing and sequence of simulated rainfalls used, combined with the properties of the evaluated soils, were not sufficient to soil surface sealing.

\section{Literature Cited}

Albuquerque, A. W.; Lombardi Neto, F.; Srinivasan, V. S.; Santos, J. R. Manejo da cobertura do solo e de práticas conservacionistas nas perdas de solo e água em Sumé, PB. Revista Brasileira de Engenharia Agrícola e Ambiental, v.6, p.136-141, 2002. https:// doi.org/10.1590/S1415-43662002000100024

Blanco-Canqui, H.; Ruis, S. J. No-tillage and soil physical environment. Geoderma, v.326, p.164-200, 2018. https://doi.org/10.1016/j. geoderma.2018.03.011

Borges, T. K. de S.; Montenegro, A. A. de A.; Santos, T. E. M. dos; Silva, D. D. da; Silva Júnior, V. de P. e. Influência de práticas conservacionistas na umidade do solo e no cultivo do milho (Zea mays L.) em Semiárido Nordestino. Revista Brasileira de Ciência do Solo, v.38, p.1862-1873, 2014. https://doi.org/10.1590/S0100-06832014000600021

Bullock, P.; Fedoroff, N.; Jongerius, A.; Stoops, G.; Tursina, T. Handbook for soil thin section description. Wolverhampton: Waine Research Publications, 1985. 152p.

Castro, L. G.; Cogo, N. P.; Volk, L. B. da S. Alteração na rugosidade superficial do solo pelo preparo e pela chuva e sua relação com a erosão hídrica. Revista Brasileira de Ciência do Solo, v.30, p.339352, 2006. https://doi.org/10.1590/S0100-06832006000200014
Castro, S. S.; Cooper, M.; Santos, M. C.; Vidal-Torrado, P. Micromorfologia do solo: Bases e aplicações. In: Curi, N.; Marques, J. J.; Guilherme, L. R. G.; Lima, J. M.; Lopes, A. S.; Alvarez V., V. H. Tópicos em ciência do solo. Viçosa: Sociedade Brasileira de Ciência do Solo, 2003. Cap.3, p.107-164.

Cogo, N. P. Uma contribuição à metodologia de estudo das perdas de erosão em condições de chuva natural: Sugestões gerais, medição dos volumes, amostragem e quantificação de solo e água da enxurrada ( $1^{\text {a }}$ aproximação). In: Encontro Nacional de Pesquisa sobre Conservação do Solo, 2, 1978, Passo Fundo. Anais... Passo Fundo: Embrapa-CNPT, 1978. p.75-98.

EMBRAPA - Empresa Brasileira de Pesquisa Agropecuária. Sistema brasileiro de classificação de solos. 3.ed. Brasília: Embrapa Informação Tecnológica, 2013. 353p.

Fox, D. M.; Bryan, R. B.; Price, A. G. The role of soil surface crusting in desertification and strategies to reduce crusting. Environmental Monitoring and Assessment, v.99, p.149-159, 2004. https://doi. org/10.1007/s10661-004-4015-5

Hamza, M. A.; Anderson, W. K. Soil compaction in cropping systems: A review of the nature, causes and possible solutions. Soil and Tillage Research, v.82, p.121-145, 2005. https://doi.org/10.1016/j. still.2004.08.009

Lima, C. A. de; Montenegro, A. A. de A.; Santos, T. E. M. dos; Andrade, E. M. de; Monteiro, A. L. N. Práticas agrícolas no cultivo da mandioca e suas relações com o escoamento superficial, perdas de solo e água. Revista Ciência Agronômica, v.46, p.697-706, 2015.

Lima, H. V. de; Lima, C. L. R. de; Leão, T. P.; Cooper, M.; Silva, A. P. da; Romero, R. E. Tráfego de máquinas agrícolas e alterações de bioporos em área sob pomar de laranja. Revista Brasileira de Ciência do Solo, v.29, p.677-684, 2005. https://doi.org/10.1590/ S0100-06832005000500003

Murphy, C. P. Thin section preparation of soils and sediments. Berkhamsted: Academic Publication, 1986. 145p.

Murphy, C. P.; Bullock, P.; Turner, R. H. The measurement and characterization of voids in soil thin sections by image analysis: Part I - Principles and techniques. Journal of Soil Science, v.98, p.498508, 1977. https://doi.org/10.1111/j.1365-2389.1977.tb02258.x

Rosa, J. D.; Cooper, M.; Darboux, F.; Medeiros, J. C. Processo de formação de crostas superficiais em razão de sistemas de preparo do solo e chuva simulada. Revista Brasileira de Ciência do Solo, v.37, p.400-410, 2013. https://doi.org/10.1590/S010006832013000200011

Sandin, M.; Jarvis, N.; Larsbo, M. Consolidation and surface sealing of nine harrowed Swedish soils. Soil \& Tillage Research, v.181, p.82-92, 2018. https://doi.org/10.1016/j.still.2018.03.017

Santos, T. E. M. dos; Montenegro, A. A. de A. Erosividade e padrões hidrológicos de precipitação no agreste central pernambucano. Revista Brasileira de Engenharia Agrícola e Ambiental, v.16, p.871880, 2012. https://doi.org/10.1590/S1415-43662012000800009

Santos, T. E. M. dos; Montenegro, A. A. de A.; Pedrosa, M. E. R. Características hidráulicas e perdas de solo e água sob cultivo do feijoeiro no semi-árido. Revista Brasileira de Engenharia Agrícola e Ambiental, v.13, p.217-225, 2009. https://doi.org/10.1590/S141543662009000300001

Silva, J. V. da; Alecrim, M. A. B.; Silva, D. de O.; Costa, C. C. da; Oliveira, R. J. de. Perdas de solo e água por erosão hídrica em floresta equiânea em um Latossolo Vermelho - Amarelo. Revista Brasileira de Ciências Agrárias, v.5, p.579-584, 2010. https://doi. org/10.5039/agraria.v5i4a724 
Silva, V. P. R. da; Pereira, E. R. R.; Azevedo, P. V. de; Sousa, F. de A. S. de; Sousa, I. F. de. Análise da pluviometria e dias chuvosos na região Nordeste do Brasil. Revista Brasileira de Engenharia Agrícola e Ambiental, v.15, p.131-138, 2011. https://doi.org/10.1590/S1415-43662011000200004
Valentin, C.; Bresson, L. M. Morphology, genesis and classification of surface crusts in loamy and sandy soils. Geoderma, v.55, p.225-245, 1992. https://doi.org/10.1016/00167061(92)90085-L 